http://journal.uinsgd.ac.id/index.php/biodjati

\title{
TOTAL LACTIC ACID, PROTEIN, FAT, AND CARBOHYDRATES IN CURD KEFIR AND COW COLOSTRUM KEFIR
}

\author{
Tuti Kurniati $^{1 *}$, Neneng Windayani ${ }^{2}$, Milla Listiawati ${ }^{3}$
}

Received : September 05, 2020

Accepted : October 30, 2020

DOI: 10.15575/biodjati.v5i2.9668

1,3 Department of Biology Education, Faculty of Tarbiyah and Teacher training UIN Sunan Gunung Djati Bandung, Jl. Cimencrang, Panyileukan, Cimencrang, Gedebage, Kota Bandung, Jawa Barat 40292

${ }^{2}$ Department of Chemistry Education, Faculty of Tarbiyah and Teacher training UIN Sunan Gunung Djati Bandung, Jl. Cimencrang, Panyileukan, Cimencrang, Gedebage, Kota Bandung, Jawa Barat 40292

e-mail:

*1tuti.kurniati@uinsgd.ac.id

2nenengwinda.ftk@uinsgd.ac.id

${ }^{3}$ millalistiawati@uinsgd.ac.id

*Corresponding author
Abstract. There are differences in the content of lactic acid, fat, protein and carbohydrates in the curd kefir and colostrum kefir. The aims of this study were to determine the content of lactic acid, protein, fat, and carbohydrates of curd kefir and colostrum kefir based on the concentration of starter and fermentation time. Experimental data were collected from a number of experiments at a temperature of $28^{\circ} \mathrm{C}$. The method used was the experimental method of CRD $3 \times 3$ with 3 replications, the data were analyzed by analysis of variance. Good kefir contained high lactic acid, proteins, and carbohydrate and low in fat. The results showed curd kefir with the highest lactic acid content of $1.59 \%$ was at a starter concentration of $20 \%$ and a fermentation time of 72 hours (d2w3), the highest protein of $2.20 \%$ was at a starter concentration of $30 \%$ and a fermentation time of 72 hours (d3w3), the lowest fat of $1.16 \%$ found at a starter concentration of $30 \%$ and a fermentation time of 72 hours (d3w3), and the highest carbohydrate of $4.81 \%$ found at a starter concentration of $30 \%$ and a fermentation time of 72 hours (d3w3). Whereas in colostrum kefir with the highest lactic acid content of $2.83 \%$ found at a starter concentration of $20 \%$ and a fermentation time of 72 hours (d2w3), the highest protein of $6.13 \%$ was at a starter concentration of $10 \%$ and a fermentation time of 24 hours (d1w1), the lowest fat of $1.58 \%$ was at a starter concentration of $30 \%$ and fermentation time of 24 hours (d3w1) and the highest carbohydrate content of $17.91 \%$ was at a starter concentration of $30 \%$ and a fermentation time of 72 hours (d3w3). It can be concluded that the starter concentration and fermentation time have a significant effect $(\alpha<0.05)$ on lactic acid, protein, fat, and carbohydrates content of curd kefir and kefir colostrum.

Keywords: carbohydrates, colostrum kefir, curd kefir, fat, lactic acid, protein

\section{Citation}

Kurniati, T., Windayani, N. \& Listiawati, M. (2020). Total Lactic Acid, Protein, Fat and Carbohydrates in Curd Kefir and Cow Colostrum Kefir. Jurnal Biodjati, 5(2), 271-280.

\section{INTRODUCTION}

Lately, the demand for functional food has increasing trends globally, along with awareness to reduce disease risk and improve health quality (Rolim, 2015; Balthazar, 2017).
Indonesia is listed as one of the largest markets for functional food in Southeast Asia (Pratiwi, 2017). Several types of functional food have been circulating among the public, including probiotic milk products such as yogurt, kefir, and koumiss (Roy, 2018). Kefir 


\section{JURNAL BIDDJATI}

http://journal.uinsgd.ac.id/index.php/biodjati

is a milk product fermented using lactic acid bacteria (LAB) such as Lactobacillus lactis, Lactobacillus delbrueckii sub sp. bulgaricus with yeast producing lactic acid and ethanol (Rosa, 2017). The LAB based on Gul (2018) plays a role in producing lactic acid and flavor components, while yeast produces carbon dioxide and alcohol. That is why the taste of kefir is not only sour but also has a little soda taste which makes it taste fresher when consumed.

For a long time, kefir has been believed to have various health benefits (Bengoa, 2018), including as an antioxidant (Chen et al., 2015), anticancer (Dos Ries et al., 2017), antidiabetic (Al-Shemmari, 2018), and antiodor of petai, Parkia speciossa Hassk (Kurniati et al., 2018). However, research on colostrum kefir has not been widely found. Colostrum kefir is a cow's colostrum fermented by kefir grains.

According to Singh (2017), curd kefir is a creamy white cream that is formed due to the fermentation process of milk with kefir grain. Curd kefir is formed during the process of making kefir. The nutritional content of curd kefir has been researched, curd kefir contains $0.7 \%$ lactic acid, $1.4 \%$ protein, $2.30 \%$ fat, and $3.15 \%$ carbohydrates (Kurniati et al., 2018), while the nutritional content of cow kefir colostrum has not yet known, so it is necessary to conduct research on cow kefir colostrum to determine its nutritional content.

Cow's colostrum can be defined as a yellow liquid released by lactating cows after giving birth for about 24 to 168 hours (Roshanzamir, 2020). The difference between colostrum and milk lies in its content. A 100 $\mathrm{mL}$ Milk or fresh milk contains $14 \mathrm{~g}$ of cal, $7.9 \mathrm{~g}$ fat, $7.7 \mathrm{~g}$ protein, and $11.7 \mathrm{~g}$ carbohydrates, while the nutrition contained in colostrum is $2.3 \%$ lactic acid, $4.7 \%$ protein, $2.7 \%$ fat, and $13.6 \%$ carbohydrates (Proximate Test
Result). In Indonesia also the world, producing kefir from colostrum has not been widely done. According to Hopker (2020), sometimes colostrum was removed if the production is excessive from early lactating cows because it is considered substandard milk which is rejected if deposited, this is very detrimental to smallholder breeders. Colostrum is very susceptible to microbial contamination (Santos et al., 2017) and is not resistant to heating due to high levels of protein (McGrath et al., 2016). Proper handling is needed so that its function can be maximally utilized for human health. This study was conducted to investigate the nutritional differences between curd kefir and colostrum kefir by fermenting cow's milk and colostrum using kefir probiotics. Therefore, this research was studied further regarding the optimum fermentation conditions and the best dosage to obtain curd kefir and cow colostrum kefir.

\section{MATERIALS AND METHODS}

The research was conducted at the Laboratory of Biology Education and Chemical Education in Integrated Laboratory of UIN Sunan Gunung Djati Bandung. This research was conducted from May until June 2018.

The material used in the study was pasteurized cow's colostrum from a dairy farm in Lembang, Bandung. The LAB isolate in the form of grain kefir was obtained from the kefir house. The tools used were petri dishes, Erlenmeyer flasks, volumetric flasks, test tube racks, test tubes, volumetric pipettes, drop pipettes, analytical scales, 100 cc measuring cups, incubators, refrigerators, burettes, methylated lamps, cotton, matches, label paper, scissors, $\mathrm{pH}$ meter, 1000 $\mathrm{mL}$ volume plastic jar, funnel, stirrer, $70 \%$ alcohol, rubber, $0.5 \mathrm{~cm}$ diameter plastic hose. 


\section{JURNAL BIDDJATI}

http://journal.uinsgd.ac.id/index.php/biodjati

\section{Producing Curd Kefir}

Kefir was made based on Listiawati et al. (2019) research method. First, cow's milk was incubated with kefir grain until it forms two layers. Then, stirred until curd kefir was produced. After that, the nutritional content of curd kefir was tested by proximate testing based on concentration and time. This proximate test was conducted to determine the fatty acids, proteins, fats, and carbohydrates found in curd kefir. The method of this stage was experimenting using a completely randomized design (CRD) with factorial patterns, the first factor is the concentration (d), and the second factor is time (w). $3 \times 3$ pattern with 3 repetitions, with inoculum concentrations (d) each $\mathrm{d} 1=10 \%, \mathrm{~d} 2=20 \%$, and $\mathrm{d} 3=30 \%$ and fermentation time $(\mathrm{w})$ each $\mathrm{w} 1=24$ hours, $\mathrm{w} 2=$ 48 and $w 3=72$ hours (Table 1 ). The variables observed were the nutritional content of the curd kefir fermentation products, namely lactic acid, protein, fat, and carbohydrates.

\section{Producing Colostrum Kefir}

Colostrum kefir was made by incubating cow's colostrum with kefir grains until it forms three layers. Then, it stirred until the kefir colostrum was produced. After that, the proximate tested was conducted based on concentration and time to determine the nutritional content, especially lactic acid, protein, fat, and carbohydrates found in colostrum kefir. The method of this stage is experimental with a completely randomized design (CRD) with factorial patterns, namely the first factor, concentration (d), and the second factor, time (w). $3 \times 3$ pattern with 3 repetitions, with inoculum concentrations (d) d1 $=10 \%, \mathrm{~d} 2=20 \%$, and $\mathrm{d} 3=30 \%(\mathrm{~b} / \mathrm{v})$ and fermentation time $(\mathrm{w}) \mathrm{w} 1$ $=24$ hours, $\mathrm{w} 2=48$ and $\mathrm{w} 3=72$ hours. The variables observed were the nutritional content of colostrum kefir fermentation products, namely lactic acid, protein, fat, and carbohydrates.

Table 1. Combination of Whey Kefir Fermentation Treatment Based on Starter Concentration and Fermentation Time

\begin{tabular}{cccccccccc}
\hline & \multicolumn{1}{c}{ Starter Concentration (d) } \\
\cline { 2 - 10 } Fermentation Time (w) & \multicolumn{3}{c}{$10 \%(\mathrm{~d} 1)$} & \multicolumn{3}{c}{$20 \%(\mathrm{~d} 2)$} & & $30 \%(\mathrm{~d} 3)$ \\
\hline 24 hours (w1) & $1 \mathrm{~d} 1 \mathrm{w} 1$ & $2 \mathrm{~d} 1 \mathrm{w} 1$ & $3 \mathrm{~d} 1 \mathrm{w} 1$ & $1 \mathrm{~d} 2 \mathrm{w} 1$ & $2 \mathrm{~d} 2 \mathrm{w} 1$ & $3 \mathrm{~d} 2 \mathrm{w} 1$ & $1 \mathrm{~d} 3 \mathrm{w} 1$ & $2 \mathrm{~d} 3 \mathrm{w} 1$ & $3 \mathrm{~d} 3 \mathrm{w} 1$ \\
48 hours (w2) & $1 \mathrm{~d} 1 \mathrm{w} 2$ & $2 \mathrm{~d} 1 \mathrm{w} 2$ & $3 \mathrm{~d} 1 \mathrm{w} 2$ & $1 \mathrm{~d} 2 \mathrm{w} 2$ & $2 \mathrm{~d} 2 \mathrm{w} 2$ & $3 \mathrm{~d} 2 \mathrm{w} 2$ & $1 \mathrm{~d} 3 \mathrm{w} 2$ & $2 \mathrm{~d} 3 \mathrm{w} 2$ & $3 \mathrm{~d} 3 \mathrm{w} 2$ \\
72 hours (w3) & $1 \mathrm{~d} 1 \mathrm{w} 3$ & $2 \mathrm{~d} 1 \mathrm{w} 3$ & $3 \mathrm{~d} 1 \mathrm{w} 3$ & $1 \mathrm{~d} 2 \mathrm{w} 3$ & $2 \mathrm{~d} 2 \mathrm{w} 3$ & $3 \mathrm{~d} 2 \mathrm{w} 3$ & $1 \mathrm{~d} 3 \mathrm{w} 3$ & $2 \mathrm{~d} 3 \mathrm{w} 3$ & $3 \mathrm{~d} 3 \mathrm{w} 3$ \\
\hline
\end{tabular}

\section{Data Analysis}

Nutritional content data based on proximate analysis was statistically tested with analysis of variance (ANOVA) and if there were differences, it was further tested with Duncan's Multiple distance test with a significant level of 5\% (Permanasari et al., 2010). Furthermore, the content of lactic acid was tested using total acid titration methods (Zhi, 2003; Jamshidian et al., 2010), protein, fat, and carbohydrates in curd kefir and colostrum kefir through proximate analysis. The nutri- tional content was analyzed by a proximate assay based on a modified AOAC (Association of Official Agricultural Chemists) method (1984) for protein, fat, and carbohydrate content.

\section{RESULTS AND DISCUSSION}

The starter concentration and fermentation time was significantly affect the increase of lactic acid content in curd kefir and colostrum kefir (Table 1). This is due to the acti- 


\section{JURNAL BIDDJATI}

http://journal.uinsgd.ac.id/index.php/biodjati

vity of acid-producing microbes that convert carbohydrates (lactose) into lactic acid. Amorim (2019) stated that lactic acid is produced from the breakdown of lactose and sucrose through the process of carbohydrate metabolism. In optimal conditions, the LAB at room temperature can convert $95 \%$ of glucose into lactic acid (Ismail, 2018). Based on Nikolaou (2019), kefir has an acidity value ranging from $0.85 \%$ to $1 \%$. While the results of Temiz's research (2017) the value of kefir acidity ranges from $0.57-0.75 \%$. The increase in total kefir acid was due to the mutually beneficial activity of LAB and yeast. Iskandar (2019) explained that during the fermentation process $\mathrm{LAB}$ converts lactose into lactic acid to convert ethanol from the results of carbohydrate breakdown by Saccharomyces cerevisiae.

Curd kefir is a first derived kefir (parent culture) from kefir grain so it can be used as a practical starter (Afiati, 2018; Sulmiyati, 2019). The research data on the nutritional content test from the first to the third day of curd kefir showed an increase in protein and carbohydrate levels, but a decrease in fat levels.

The increase in protein content at the treatment of (d1w1), the protein content was $0.87 \%$, and at the treatment of $(\mathrm{d} 3 \mathrm{w} 3)$, the protein content was increase to $2.20 \%$, there was an increase of $1.33 \%$ (Table 3). Carbohydrate content also increased. The carbohydrates increase at the treatment of ( $11 \mathrm{w} 1)$ from $1.29 \%$ to $4.81 \%$ at the treatment of (d3w3). It was an increase of $3.52 \%$ (Table 5 ). The decrease in fat content at the treatment of ( $\mathrm{d} 2 \mathrm{w} 1)$, the fat was $2.37 \%$ and at the treatment of $(\mathrm{d} 3 \mathrm{w} 3)$, the fat content was decreased to $1.16 \%$. it was a decrease of $1.21 \%$ (Table 4).

At the beginning of milking, the number of active compounds in the colostrum of dairy cows was quite high, one of the bioactive compounds is lactoferrin, an anti-micro- bial substance. As the fermentation time went on from day 2 to day 3 , the fermentation process began to decline indicating by the chemical quality of colostrum that are protein and fat compounds begin to decline. This shows that the longer the time, the higher the acid content, besides that the more the starter, the higher the acid content. This is similar to the results of research by Lankey \& Balia (2014) which stated the same thing.

The result of the nutritional content analysis of colostrum kefir showed the highest protein content of $6.13 \%$ was in the $10 \%$ dose treatment, 24 hours fermentation time (d1w1). It was significantly $(\alpha<0.05)$ higher than other treatments. The research data showed that the lowest fat content was found in the $30 \%$ dose treatment with the fermentation time of 72 hours $(\mathrm{d} 3 \mathrm{w} 3)$ and it was significantly $(\alpha$ $<0.05)$ lower than other treatments. The result also showed that the highest carbohydrate content was in the $30 \%$ of starter concentration with the fermentation time of 72 hours (d3w3), and it was significantly $(\alpha<0.05)$ higher than other treatments.

\section{Lactic Acid Content}

The lactic acid content analysis was carried out to determine the lactic acid content in curd kefir and cow's colostrum kefir based on the concentration of starter and fermentation time (Table 2).

The treatment that produces the highest lactic acid content in curd kefir is a starter concentration of $20 \%(\mathrm{~d} 2)$ and a fermentation time of 72 hours (w3) which produced $1.59 \%$ of lactic acid (Table 2). While the lowest lactic acid content is at a starter concentration of $10 \%(\mathrm{~d} 1)$ and 24 hours fermentation time (w1), with a lactic acid content of $1.07 \%$. Whereas the treatment that produced the highest lactic acid content in colostrum kefir was a starter concentration of $20 \%(\mathrm{~d} 1)$ and a fermentation 


\section{JURNAL BIDDJATI}

http://journal.uinsgd.ac.id/index.php/biodjati

time of 72 hours (w3) which produced $2.83 \%$ of lactic acid, while the lowest lactic acid content was at a starter concentration of $10 \%$ (d1) and time of 24 hours fermentation (w1) with lactic acid content $1.96 \%$. This research was in accordance with Herawati \& Wibawa (2011) that reported the higher the concentration of skim milk and the longer the fermen- tation time caused an increase in the levels of protein, fat, ash, total lactic acid, and lean dry weight. This is because the higher the concentration of skim milk added will increase the activity of Streptococcus thermophillus and Lactobacillus bulgaricus which are used in fermentation.

Table 2. Average of lactic acid content based on starter concentration and fermentation time

\begin{tabular}{cccc}
\hline Starter Concentration & Fermentation Time & \multicolumn{2}{c}{ Average (\%) } \\
\cline { 3 - 4 } (d) & (w) & Curd Kefir & Colostrum Kefir \\
\hline d1 & w1 & 1.07 & $1.96 \mathrm{a}$ \\
d1 & w2 & 1.12 & $1.97 \mathrm{a}$ \\
d1 & w3 & 1.15 & $1.98 \mathrm{a}$ \\
d2 & w1 & 1.40 & $2.64 \mathrm{c}$ \\
d2 & w2 & 1.41 & $2.50 \mathrm{~b}$ \\
d2 & w3 & 1.59 & $2.83 \mathrm{~d}$ \\
d3 & w1 & 1.40 & $2.52 \mathrm{~b}$ \\
d3 & w2 & 1.42 & $2.50 \mathrm{~b}$ \\
d3 & w3 & 1.41 & $2.46 \mathrm{~b}$ \\
\hline
\end{tabular}

The numbers followed by the same letters in the same column show no significant difference based on Duncan's test at the $95 \%$ significance level

\section{Protein Content}

The protein content analysis was carried out to determine the protein content in curd kefir and colostrum kefir based on the concentration of starter and fermentation time, (Table 3).

The treatment that produces the highest protein content in curd kefir is a starter concentration of $30 \%(\mathrm{~d} 3)$ and a fermentation time of 72 hours (w3) which produced $2.20 \%$ of protein, while the lowest protein content is at a starter concentration of $10 \%(\mathrm{~d} 1)$ and time of 24 hours fermentation (w1) with protein content of $0.87 \%$ (Table 3 ). Whereas, a treatment that produced the highest protein content in colostrum kefir was a starter concentration of $10 \%(\mathrm{~d} 1)$ and 24 -hour fermentation time (w1) with $6.13 \%$ of protein, while the lowest protein content was at a starter concentration of $30 \%(\mathrm{~d} 3)$ and fermentation time of 24-hour (w1) which produced $3.53 \%$ of protein.

Table 3. Average of protein content based on starter concentration and fermentation time

\begin{tabular}{cccc}
\hline Starter Concentration & Fermentation Time & \multicolumn{2}{c}{ Average (\%) } \\
\cline { 3 - 4 } (d) & (w) & Curd Kefir & Colostrum Kefir \\
\hline d1 & w1 & 0.87 & $6.13 \mathrm{~h}$ \\
d1 & w2 & 0.97 & $5.29 \mathrm{f}$ \\
d1 & w3 & 1.13 & $6.07 \mathrm{~g}$ \\
d2 & w1 & 1.21 & $4.60 \mathrm{c}$ \\
d2 & w2 & 1.34 & $4.80 \mathrm{~d}$ \\
d2 & w3 & 1.41 & $5.12 \mathrm{e}$ \\
d3 & w1 & 1.58 & $3.53 \mathrm{a}$ \\
d3 & w2 & 1.93 & $3.65 \mathrm{~b}$ \\
d3 & w3 & 2.20 & $3.60 \mathrm{~b}$ \\
\hline
\end{tabular}

The numbers followed by the same letters in the same column show no significant difference based on Duncan's test at the $95 \%$ significance level 


\section{JURNAL BIDDJATI}

http://journal.uinsgd.ac.id/index.php/biodjati

The increase of protein in curd kefir occurs due to the yeast fermentation process which produces ethanol and $\mathrm{CO}_{2}$ that stimulating the growth of L. bulgaricus to produces proteolytic that converts protein into peptides and amino acids (Vianaa, 2017; Laureys, 2018). There is a degradation of protein into amino acids due to the presence of the protease enzyme (Liu, 2017). This causes protein content tends to increase.

\section{Fat Content}

The fat content analysis was carried out to determine the fat content in curd kefir and kefir colostrum based on the concentration of starter and fermentation time (Table 4).
Based on Table 4, a treatment that produces the highest fat content in curd kefir is a starter concentration of $10 \%(\mathrm{~d} 1)$ and a fermentation time of 48 hours (w2) which produced $2.37 \%$ of fat, while the lowest fat content is at a starter concentration of $30 \%(\mathrm{~d} 3)$ and time fermentation of 72 hours (w3) with $1.16 \%$ of fat. Whereas a treatment that produced the highest fat content in colostrum kefir was a starter concentration of $10 \%$ (d1) and a 24 hour fermentation time (w1) with $4.39 \%$ of fat, while the lowest fat content was at a starter concentration of $30 \%(\mathrm{~d} 3)$ and a fermentation time of 72 . hour (w3) with the fat content of $1.98 \%$.

Table 4. Average of fat content based on starter concentration and fermentation time

\begin{tabular}{cccc}
\hline Starter Concentration & Fermentation Time & \multicolumn{2}{c}{ Average (\%) } \\
\cline { 3 - 4 } (d) & (w) & Curd Kefir & Colostrum Kefir \\
\hline d1 & w1 & 2.30 & $4.39 \mathrm{~h}$ \\
d1 & w2 & 2.37 & $4.18 \mathrm{~g}$ \\
d1 & w3 & 2.17 & $3.92 \mathrm{f}$ \\
d2 & w1 & 2.09 & $2.10 \mathrm{~d}$ \\
d2 & w2 & 1.93 & $2.13 \mathrm{~d}$ \\
d2 & w3 & 1.89 & $2.60 \mathrm{e}$ \\
d3 & w1 & 1.50 & $1.58 \mathrm{a}$ \\
d3 & w2 & 1.46 & $1.92 \mathrm{~b}$ \\
d3 & w3 & 1.16 & $1.98 \mathrm{c}$ \\
\hline
\end{tabular}

The numbers followed by the same letters in the same column show no significant difference based on Duncan's test at the $95 \%$ significance level

Furthermore, the fermentation process causes the fat content of curd kefir and colostrum kefir to decrease. The starter concentration and fermentation time have a significant effect $(\alpha<0.05)$ to decrease the fat content of curd and colostrum kefir (Table 4). Izquierdo-González (2019) stated that the longer the ripening, the $\mathrm{LAB}$ proliferation will increase and also produce more lipase enzymes so more fat is hydrolyzed, resulting in lower levels of fat.

\section{Carbohydrate Content}

The carbohydrate content analysis was carried out to determine the carbohydrate content of curd kefir and colostrum kefir based on the concentration of starter and fermentation time (Table 5).

The treatment that produces the highest carbohydrate content in curd kefir is starter concentration of $30 \% \mathrm{~g}(\mathrm{~d} 3)$ and fermentation time of 72 hours (w3) which produced $4.81 \%$ of carbohydrate, while the lowest carbohydrate content is on a starter concentration of $10 \%(\mathrm{~d} 1)$ and 24 hours fermentation (w1) with $1.29 \%$ of carbohydrate (Table 5). Whereas the treatment that produced the highest carbohydrate content in colostrum kefir was on 


\section{JURNAL BIDDJATI}

http://journal.uinsgd.ac.id/index.php/biodjati

$30 \%(\mathrm{~d} 3)$ starter concentration and 72 hour fermentation time (w3) with $17.91 \%$ of carbohydrate, while the lowest carbohydrate content was at starter concentration of $10 \%$ (d1) and fermentation time of 72 hours (w3) with $8.74 \%$ of carbohydrate.

The carbohydrate content was significantly $(\alpha<0.05)$ increased by different starter concentration and fermentation time (Table 5). This is due to the activity of yeast which produces maltose enzymes that convert carbohydrates into maltose (Hikmetoglu, 2020). Kim (2018) stated that in the kefir fermentation process, LAB and yeast convert complex organic molecular compounds such as proteins, carbohydrates, and fats into simple compounds that are easy to dissolve and have high digestibility.

Taken together, it can be concluded that the concentration of starter and fermentation time has a significant effect $(\alpha<0.05)$ on the content of lactic acid, protein, fat, and carbohydrates in curd kefir and colostrum kefir. The results of the nutritional content analysis of the curd kefir and the colostrum kefir nutritional content showed the high lactic acid content. Further research need to be carried out to determine the total plate count of probiotics and bioactivity of colostrum kefir as fuctional food.

Table 5. Average of Carbohydrate content based on starter concentration and fermentation time

\begin{tabular}{cccc}
\hline Starter Concentration & Fermentation Time & \multicolumn{2}{c}{ Average (\%) } \\
\cline { 3 - 4 } (d) & (w) & Curd Kefir & Colostrum Kefir \\
\hline d1 & w1 & 1.29 & $9.16 \mathrm{~b}$ \\
d1 & w2 & 3.17 & $10.57 \mathrm{c}$ \\
d1 & w3 & 4.18 & $8.74 \mathrm{a}$ \\
d2 & w1 & 1.37 & $13.45 \mathrm{~d}$ \\
d2 & w2 & 3.18 & $14.30 \mathrm{f}$ \\
d2 & w3 & 4.28 & $13.58 \mathrm{e}$ \\
d3 & w1 & 2.47 & $17.68 \mathrm{~h}$ \\
d3 & w2 & 3.60 & $17.47 \mathrm{~g}$ \\
d3 & w3 & 4.81 & $17.91 \mathrm{i}$ \\
\hline
\end{tabular}

The numbers followed by the same letters in the same column show no significant difference based on Duncan's test at the $95 \%$ significance level

\section{ACKNOWLEDGEMENTS}

Thanks to LP2M UIN Sunan Gunung Djati Bandung, Integrated Laboratory of UIN Sunan Gunung Djati Bandung, and UNPAD Animal Husbandry Laboratory for assistance in carrying out this research.

\section{REFERENCES}

Afiati, F., Setiyoningrum, F. \& Priadi, G. (2018). Karakterisasi Curd Kefir Susu Sapi dengan Penambahan Umbi Bit (Beta vulgaris). Characterization of
Curd Kefir Milk with the Addition of Beetroot (Beta vulgaris). Prosiding Seminar Nasional Masyarakat Biodiversitas Indonesia Volume 4, Nomor 2. 270-273.

Al-Shemmari, I. G. M., Altaee, R. A. M. K. \& Hassan, A. H. (2018). Evaluation of the Antidiabetic and Antihyperlipidemic activity of Kefir in Alloxan-induced Diabetes Mellitus Rats. Scientific Journal of Medical Research, 2(6), 8386.

Amorim, F. G., Coitinho, L. B., Dias, A. T., Friques, A. G. F., Monteiro, B. L., 


\section{JURNAL BIDDJATI}

http://journal.uinsgd.ac.id/index.php/biodjati

de Rezende, L. C. D., Pereira, T. M. C., Campagnaro, B. P., de Pauw, E., Vasquez, E. C. \& Quinton, L. (2019). Identification of New Bioactive Peptides from Kefir Milk Through Proteopeptidomics: Bioprospection of Antihypertensive Molecules. Food Chemistry, 282, 109-119.

AOAC. (1984). Official Methods of Analysis of the Association of Official Analytical Chemist, 14th Edition Arlington. Virginia.

Balthazar, C. F., Pimentel, T. C., Ferrão, L. L., Almada, C. N., Santillo, A., Albenzio, M., Mollakhalili, N., Mortazavian, A. M., Nascimento, J. S., Silva, M. C., Freitas, M. Q., Sant'Ana, A. S., Granato, D. \& Cruz, A. G. (2017). Sheep Milk: Physicochemical Characteristics and Relevance for Functional Food Development. Comprehensive Reviews in Food Science and Food Safety, 16(2), 247-262.

Bengoa, A. A., Iraporda, C., Garrote, G. L. \& Abraham, A. G. (2018). Kefir Microorganisms: their Role in Grain Assembly and Health Properties of Fermented milk. Journal of Applied Microbiology, 126(3), 686-700.

Chen, Z., Shi, J., Yang, X., Nan, B., Liu, Y. \& Wang, Z. (2015). Chemical and Physical Characteristics and Antioxidant Activities of the Exopolysaccharide Produced by Tibetan Kefir Grains during Milk Fermentation. International Dairy Journal, 43, 15-21.

Dos Reis, S. A., da Conceição, L. L., Siqueira, N. P., Rosa, D. D., da Silva, L. L. \& Peluzio, M. do C. G. (2017). Review of the Mechanisms of Probiotic Actions in the Prevention of Colorectal Cancer. Nutrition Research, 37, 1-19.

Gul, O., Atalar, I., Mortas, M. \& Dervisoglu,
M. (2018). Rheological, Textural, Color, and Sensorial Properties of Kefir Produced with Buffalo Milk using Kefir Grains and Starter Culture: A Comparison with Cows' Milk Kefir. International Journal of Dairy Technology, 71(1), 7380.

Herawati, D. A. \& Wibawa, D. A. A. (2011). Pengaruh Konsentrasi Susu Skim dan Waktu Fermentasi terhadap Hasil Pembuatan Soyghurt. Jurnal Ilmiah Teknik Lingkungan, 1(2), 452-329.

Hikmetoglu, M., Sogut, E. \& Sogut, O. (2020). Changes in Carbohydrate Profile in Kefir Fermentation. Bioactive Carbohydrates and Dietary Fibre, 23.

Hopker A, Pandey N, Goswami J, Hopker S, Saikia R, Jennings A, Saikia, D., Sargison, N. \& Marsland, R. (2020) Colostrum Provision and Care of Calves Among Smallholder Farmers in the Kaziranga Region of Assam, India. PLoS ONE, 15(3), e0228819.

Iskandar, C. F., Cailliez-Grimal, C., Borges, F., Junelles, R. \& Marie, A. (2019). Review of lactose and galactose metabolism in Lactic Acid Bacteria dedicated to expert genomic annotation. Trends in Food Science \& Technology, 88(24), 121-132.

Ismail, Y. S., Yulvizar, C. \& Mazhitov, B. (2018). Characterization of Lactic Acid Bacteria from Local Cow's Milk Kefir. IOP Conference Series: Earth and Environmental Science, 130, 1-8.

Izquierdo-González, J. J., Amil-Ruiz, J., Zazzu, S., Sánchez-Lucas, R., Fuentes-Almagro, C. A. \& Rodríguez-Ortega, M. J. (2019). Proteomic Analysis of Goat Milk Kefir: Profiling the Fermentation-time Dependent Protein Digestion and Identification of Potential Peptides with Biological Activity. Food Chemis- 


\section{JURNAL BIDDJATI}

http://journal.uinsgd.ac.id/index.php/biodjati

try, 295, 456-465.

Jamshidian, M., Tehrany, E. A., Imran, M., Jacquot, M. \& Desobry, S. (2010). Polylactic Acid: Production, Applications, Nanocomposites, and Release Studies. Comprehensive Reviews in Food Science and Food Safety, 9(5), 552-571.

Kim, D., Jeong, D., Song, K. \& Seo, K. (2018). Comparison of Traditional and Backslopping Methods for Kefir Fermentation Based on Physicochemical and Microbiological Characteristics. LWT - Food and Science Technology, 97, 503-507.

Kurniati, T., Windayani, N. \& Listiawati, M. (2018). Anti Odor Activity of Milk Kefir on Organosulfur Polysulfide Cyclic Compounds in Petai (Parkia speciosa Hassk). Journal of Physics: Conference Series 5th International Seminar of Mathematics, Science, and Computer Science Education.

Laureys, D., Aerts, M. \& Vandamme, P. (2018). Oxygen and Diverse Nutrients Influence the Water Kefir Fermentation Process. Food Microbiology, 73, 351361.

Lengkey, H. A. W. \& Balia, R. L. (2014). The Effect of Starter Dosage and Fermentation Time on $\mathrm{pH}$ and Lactic acid production. Biotechnology in Animal Husbandry, 30(2), 339-347.

Listiawati, M., Kurniati, T. \& Windayani, N. (2019). An Effective Alternative of Predawn Meal Using Milk Kefir. Journal of Physics: Conference Series IOP Publishing, 1402(5), 1-6.

Liu, Y. \& Pischetsrieder, M. (2017). Identification and Relative Quantification of Bioactive Peptides Sequentially Released during Simulated Gastrointestinal Digestion of Commercial Kefir. $J$. Agric. Food Chem, 65(9), 1865-1873.
McGrath, B. A., Fox, P. F., Mcsweeney, P. L. H. \& Kelly, A. L. (2016). Composition and Properties of Bovine Colostrum: a Review. Journal Science and Technology, 96, 133-158.

Nikolaou, A., Tsakiris, A., Kanellaki, M., Bezirtzoglou, E., Akrida-Demertzki, K. \& Kourkoutas, Y. (2019) Wine Production Using Free and Immobilized Kefir Culture on Natural Supports. Food Chemistry, 272, 39-48.

Permanasari, A. E., Rambli, D. R. A. \& Dominic, P. D. D. (2010). Forecasting Method Selection Using ANOVA and Duncan Multiple Range Tests on Time Series Dataset. In 2010 International Symposium on Information Technology Vol. 2. 941-945.

Pratiwi, R. \& Purwestri, Y.A. ( 2017). Black Rice as a Functional Food in Indonesia. Functional Foods in Health and Disease, 7(3), 182-194.

Rolim, P. M. (2015). Development of Prebiotic Food Products and Health Benefits. Food Sci. Technol (Campinas), 35(1), 3-10.

Rosa, D. D., Dias, M. M. S., Grześkowiak, Ł. M., Reis, S. A., Conceição, L. L. \& Peluzio, M. do C. G. (2017). Milk Kefir: Nutritional, Microbiological, and Health Benefits. Nutrition Research Reviews, 30, 82-96.

Roshanzamir, H., Rezaei, J. \& Fazaeli, H. (2020). Colostrum and Milk Performance, and Blood Immunity Indices and Minerals of Holstein Cows Receiving organic $\mathrm{Mn}, \mathrm{Zn}$, and $\mathrm{Cu}$ sources. Animal Nutrition, 6(1), 61-68.

Roy P. \& Kumar, V. (2018). Functional Food: Probiotic as Health Booster. Journal Food Nutrition and Population Health, 2(2), 1-3.

Santos, G., Thaís, J. \& Hermelina, F. (2017). 


\section{JURNAL BIDDJATI}

http://journal.uinsgd.ac.id/index.php/biodjati

Nutritional and Microbiological Quality of Bovine Colostrum Samples in Brazil. Revista Brasileira de Zootecnia, 46(1), 72-79.

Singh, P. K. \& Shah N. P. (2017). Yogurt in Health and Disease Prevention Chapter 5 - Other Fermented Dairy Products: Kefir and Koumiss. London: Academic Press.

Sulmiyati, Said, N., Fahrodi, D. U., Malaka, R. \& Maruddin, F. (2019). Assessment of the Antibacterial Activity of Goat Milk Kefir on Escherichia coli ATCC 8739 and Salmonella enteric sub sp. enterica serovar typhimurium ATCC 14028 using a well diffusion method. IOP Conf. Series: Earth and Environmental Science, 247, 012051.
Temiz, H. \& Dağyıldız, K. (2017). Effects of Microbial Transglutaminase on Physicochemical, Microbial, and Sensorial Properties of Kefir Produced by Using Mixture Cows and Soymilk. Korean Journal for Food Science of Animal Resources, 37(4): 606-616.

Vianaa, R. O., Magalhães-Guedesa, K. T., Braga, R. A., Dias, D. R. \& Schwan, R. F. (2017). Fermentation Process for Production of Apple-based Kefir Vinegar: Microbiological, Chemical, and Sensory Analysis. Brazilian Journal Microbiology, 48(3), 592-601.

Zhi, Z. (2003). Study on Methods for Determination of Lactic Acid in Fermented Broth. Food Science. 